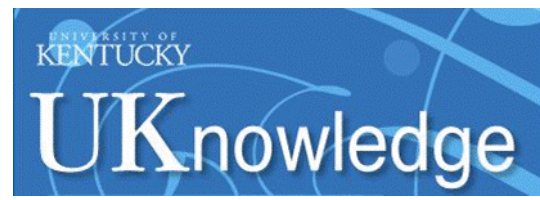

University of Kentucky

UKnowledge

Saha Cardiovascular Research Center Faculty

Publications

Cardiovascular Research

4-23-2021

\title{
Effects of Endogenous Angiotensin II on Abdominal Aortic Aneurysms and Atherosclerosis in Angiotensin II-Infused Mice
}

\author{
Masayoshi Kukida \\ University of Kentucky, Masayoshi.Kukida@uky.edu \\ Hisashi Sawada \\ University of Kentucky, hisashi.sawada@uky.edu \\ Satoko Ohno-Urabe \\ University of Kentucky, Satoko.Ohno@uky.edu \\ Deborah A. Howatt \\ University of Kentucky, deborah.howatt@uky.edu \\ Jessica J. Moorleghen \\ University of Kentucky, jjmoorl@uky.edu
}

See next page for additional authors

Follow this and additional works at: https://uknowledge.uky.edu/cvrc_facpub

Part of the Cardiology Commons, and the Circulatory and Respiratory Physiology Commons

Right click to open a feedback form in a new tab to let us know how this document benefits you.

\section{Repository Citation}

Kukida, Masayoshi; Sawada, Hisashi; Ohno-Urabe, Satoko; Howatt, Deborah A.; Moorleghen, Jessica J.; Poglitsch, Marko; Daugherty, Alan; and Lu, Hong S., "Effects of Endogenous Angiotensin II on Abdominal Aortic Aneurysms and Atherosclerosis in Angiotensin II-Infused Mice" (2021). Saha Cardiovascular Research Center Faculty Publications. 48.

https://uknowledge.uky.edu/cvrc_facpub/48

This Letter to the Editor is brought to you for free and open access by the Cardiovascular Research at UKnowledge. It has been accepted for inclusion in Saha Cardiovascular Research Center Faculty Publications by an authorized administrator of UKnowledge. For more information, please contact UKnowledge@lsv.uky.edu. 


\section{Effects of Endogenous Angiotensin II on Abdominal Aortic Aneurysms and Atherosclerosis in Angiotensin II-Infused Mice}

Digital Object Identifier (DOI)

https://doi.org/10.1161/JAHA.121.020467

Notes/Citation Information

Published in Journal of the American Heart Association, e020467.

(C) 2021 The Authors

This is an open access article under the terms of the Creative Commons Attribution-NonCommercialNoDerivs License, which permits use and distribution in any medium, provided the original work is properly cited, the use is non-commercial and no modifications or adaptations are made.

Authors

Masayoshi Kukida, Hisashi Sawada, Satoko Ohno-Urabe, Deborah A. Howatt, Jessica J. Moorleghen, Marko Poglitsch, Alan Daugherty, and Hong S. Lu 


\section{Effects of Endogenous Angiotensin II on Abdominal Aortic Aneurysms and Atherosclerosis in Angiotensin II-Infused Mice}

Masayoshi Kukida (D), MD, PhD*; Hisashi Sawada (D), MD, PhD*; Satoko Ohno-Urabe, MD, PhD; Deborah A. Howatt, BS; Jessica J. Moorleghen, BS; Marko Poglitsch, PhD; Alan Daugherty (i), PhD, DSc; Hong S. Lu (iD), MD, PhD

A ngiotensin II (Ang II) is a major effector of the reninangiotensin system and is important in regulating vascular function. Infusion of Ang II induces abdominal aortic aneurysms (AAA) and exacerbates atherosclerosis in hypercholesterolemic mice. In Ang II-infused normocholesterolemic rats, endogenous Ang II production is maintained in kidney. ${ }^{1}$ However, the effects of endogenous Ang II on AAA and atherosclerosis during Ang II infusion in hypercholesterolemic mice have not been studied.

Detailed methods and results are available in bioRxiv (https://doi.org/10.1101/2020.11.18.377416). All animal experiments were approved by the University of Kentucky Institutional Animal Care and Use Committee. SigmaPlot version 14.0 (Systat Software Inc) was used for statistical analyses. Since either normality (ShapiroWilk test) or homogeneous variation (Brown-Forsythe test) was not confirmed, all data were analyzed using nonparametric analyses. Statistical tests might be underpowered.

Our previous studies revealed that liver-specific deletion of angiotensinogen, the sole precursor of Ang II, reduced atherosclerotic lesion area with decreases of Ang II concentrations in kidney but not plasma. ${ }^{2}$ In addition, inhibition of angiotensinogen uptake into renal proximal tubular cells ameliorated atherosclerosis development. ${ }^{3}$ These results indicate an important role of renal Ang II in atherosclerosis formation. In an initial study, either vehicle or murine Ang II (1000 ng/kg per minute) was infused into male C57BL/6J mice for 7 days via osmotic pumps (Alzet model 2001, Durect Corporation). Then, we determined concentrations of angiotensin peptides in plasma and kidney by liquid chromatography-tandem mass spectrometry. Plasma Ang II concentrations were not altered by Ang II infusion (Figure $[\mathrm{A}]$ ). Consistent with a previous report, ${ }^{1}$ renal Ang II concentrations were significantly higher in Ang II-infused mice than in vehicle-infused mice (Figure $[A]$ ). Since Ang II is metabolized to Ang III and Ang(1-7) and these peptides may contribute to the pathophysiology of atherosclerosis, ${ }^{4}$ we assessed Ang III and Ang(1-7) concentrations in Ang II-infused mice. Ang(1-7) was not detectable in plasma and kidney from either vehicle- or Ang II-infused mice, and Ang III concentrations were not statistically different in plasma and kidney between infusions (Figure [B]). These results indicate that exogenous Ang II does not affect productions of major Ang II metabolites.

Since Ang I is the direct substrate of Ang II, we measured plasma and renal Ang I concentrations to evaluate the production of Ang II. Ang II infusion decreased Ang I concentrations in both plasma and kidney (Figure [C]). However, Ang II-induced reduction of Ang I concentrations was modest in kidney

Correspondence to: Hong S. Lu, MD, PhD, Saha Cardiovascular Research Center, University of Kentucky, 741 South Limestone, BBSRB Room B249, Lexington, KY 40536. E-mail: hong.lu@uky.edu

${ }^{*} \mathrm{M}$. Kukida and H. Sawada are co-first authors.

Preprint posted on BioRxiv January 22, 2021. DOI: https://doi.org/10.1101/2020.11.18.377416.

For Sources of Funding and Disclosures, see page 3.

(C) 2021 The Authors. Published on behalf of the American Heart Association, Inc., by Wiley. This is an open access article under the terms of the Creative Commons Attribution-NonCommercial-NoDerivs License, which permits use and distribution in any medium, provided the original work is properly cited, the use is non-commercial and no modifications or adaptations are made.

JAHA is available at: www.ahajournals.org/journal/jaha 


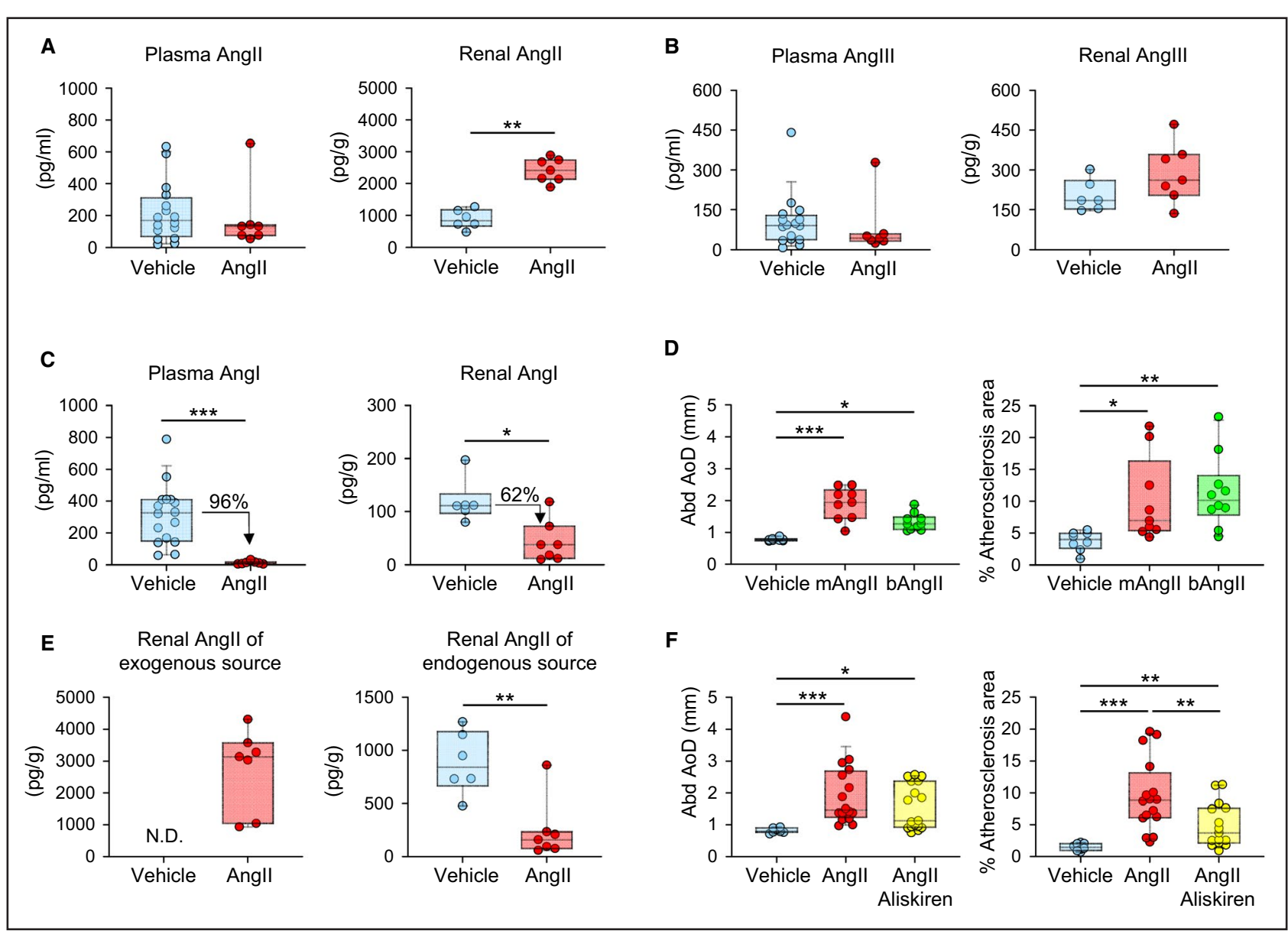

Figure. Contributions of angiotensin II (Ang II) to abdominal aortic aneurysms (AAA) and atherosclerosis in Ang II-infused mice.

Plasma and renal concentrations of (A) Ang II, (B) Ang III, and (C) Ang I in male C57BL/6J mice (8- to 10-weeks-old, The JAX \# 000664) infused with either vehicle $(n=16)$ or murine Ang II (1000 ng/kg per minute, $n=7)$ for 7 days. (D), Maximal external diameters of abdominal aorta and percent atherosclerotic lesion areas in male low-density lipoprotein receptor-deficient mice (LDLR-/-, 10-weekold; The JAX, stock \# 002207) fed a Western diet and infused with vehicle ( $\mathrm{n=8}$ ), murine Ang II (mAng II, $1000 \mathrm{ng} / \mathrm{kg} \mathrm{per} \mathrm{minute,} n=9)$, or bovine Ang II (bAng II, $1000 \mathrm{ng} / \mathrm{kg}$ per minute, $\mathrm{n}=10$ ). (E), Renal Ang II concentrations of exogenous and endogenous source in either vehicle $(\mathrm{n}=6)$ or bovine Ang II (1000 $\mathrm{ng} / \mathrm{kg}$ per minute, $\mathrm{n}=7)$-infused mice. (F), Aliskiren $(25 \mathrm{mg} / \mathrm{kg}$ per day) suppressed atherosclerotic lesion size but not abdominal aortic dilatation in LDLR-deficient mice (8-week-old) with Ang II infusion for 4 weeks (vehicle, $n=8$; $m$ Ang $\mathrm{II}, \mathrm{n}=16$; Ang II+aliskiren, $\mathrm{n}=17$ ). Angiotensin peptides were measured by liquid chromatography-tandem mass spectrometry. Data are presented as box plots drawn from the 25 th to 75 th percentiles with a line at the median. ${ }^{\star} P<0.05,{ }^{* \star} P<0.01,{ }^{* \star *} P<0.001$ by MannWhitney $U$ test or Kruskal-Wallis with Dunn method. N.D. indicates not detectable.

compared with those in plasma $(96 \%$ in plasma versus $62 \%$ in kidney, $P<0.05$ by Mann-Whitney $U$ test) (Figure [C]), indicating persistent renal Ang II production during Ang II infusion. We next investigated the presence of endogenous Ang II in kidney of Ang II-infused mice. Bovine Ang II differs from murine Ang II (Asp-Arg-Val-Tyr-Ile-His-Pro-Phe) in the fifth amino acid being Val (Asp-Arg-Val-Tyr-Val-His-ProPhe). The 1 amino acid difference results in a mass difference that enabled distinction between bovine and murine Ang II by liquid chromatography-tandem mass spectrometry as exogenous and endogenous sources, respectively, in bovine Ang II-infused mice. Bovine Ang II exerted comparable effects to murine Ang II on AAA and atherosclerosis formation in male low-density lipoprotein receptor-deficient mice fed a Western diet (Figure [D]), indicating that bovine Ang II infusion mimicked murine Ang II infusion-induced renin-angiotensin system regulation in mice. As expected, bovine Ang II infusion increased exogenous Ang II concentrations in kidney (Figure [E]). The median of renal endogenous Ang II concentrations in vehicle-infused mice was $843 \mathrm{pg} / \mathrm{g}$ (interquartile range, 669-1179 pg/g) (Figure [E]). Ang II infusion reduced endogenous Ang II concentrations to $161 \mathrm{pg} / \mathrm{g}$ (interquartile range, 77-235 pg/g). Endogenous Ang II was still detectable in mice with bovine Ang II infusion. Alongside the presence of renal Ang I, these data support that intrarenal Ang II production is continued during Ang II infusion. 
We next investigated whether inhibition of endogenous Ang II production attenuated AAA and atherosclerosis formation during Ang II infusion. Angiotensin-converting enzyme inhibitors or direct renin inhibitors suppress endogenous Ang II production. However, angiotensin-converting enzyme inhibitors target several other substrates such as bradykinin that may affect cardiovascular functions. To investigate the effects of endogenous Ang II on AAA and atherosclerosis formation, we administered aliskiren, a direct renin inhibitor, to inhibit endogenous Ang II production into Ang II-infused mice. Murine Ang II (1000 ng/kg per minute) was infused into low-density lipoprotein receptor-deficient mice for 28 days that led to significant augmentation of AAA and atherosclerosis. On the basis of our previous study that aliskiren infusion of $25 \mathrm{mg} / \mathrm{kg}$ per day led to maximal inhibitory effects on endogenous Ang $\mathrm{II}$ production in mice, ${ }^{5}$ we used this infusion rate of aliskiren in this experiment. As expected, continuous Ang II infusion induced AAA and augmented atherosclerotic lesions compared with vehicle infusion (Figure [F]). Aliskiren did not inhibit abdominal aortic expansion in Ang II-infused mice. Although atherosclerotic lesion size in aliskiren and Ang IIinfused mice was larger than vehicle-infused mice, aliskiren reduced lesion size significantly, compared with Ang II infusion alone. These results support that AAA development was attributed to exogenous Ang II, whereas atherosclerosis was augmented by both endogenous and exogenous Ang II.

In conclusion, renal endogenous Ang II is present in Ang II-infused mice, and endogenous Ang II contributes to Ang II-mediated atherosclerosis, but not AAA, formation in hypercholesteremic mice.

While Ang II infusion accelerates atherosclerosis formation and renal Ang II concentrations, there has not been a determination that the renal changes directly impact the vascular pathology. Proximal tubule cells (PTCs) contain angiotensinogen, renin and angiotensinconverting enzymes that are needed to generate Ang
II. ${ }^{3}$ Ang II type 1a receptors, the determinant of Ang II-induced atherosclerosis, are also present in PTCs. Therefore, we hypothesize that Ang II production in PTCs augments atherosclerosis. To test this hypothesis, mice are being developed with PTC-specific Ang II type 1a receptor genetic deficiency or PTC overexpression of human AGT and human renin.

\section{ARTICLE INFORMATION}

Received January 25, 2021; accepted March 15, 2021.

\section{Affiliations}

Saha Cardiovascular Research Center, Lexington, KY (M.K., H.S., S.O., D.A.H., J.J.M., A.D., H.S.L.); ; Department of Physiology, University of Kentucky, Lexington, KY (H.S., A.D., H.S.L.); and Attoquant Diagnostics, , Vienna, Austria (M.P.).

\section{Sources of Funding}

This work was supported by National Institutes of Health grants (R01HL139748, R01HL133723).

\section{Disclosures}

Poglitsch is an employee of Attoquant Diagnostics, Vienna, Austria. The remaining authors have no disclosures to report.

\section{REFERENCES}

1. Zou LX, Hymel A, Imig JD, Navar LG. Renal accumulation of circulating angiotensin II in angiotensin II-infused rats. Hypertension. 1996;27:658662. DOI: 10.1161/01.HYP.27.3.658.

2. Wu CH, Wu C, Howatt DA, Moorleghen JJ, Cassis LA, Daugherty A, Lu HS. Two amino acids proximate to the renin cleavage site of human angiotensinogen do not affect blood pressure and atherosclerosis in mice-brief report. Arterioscler Thromb Vasc Biol. 2020;40:2108-2113. DOI: 10.1161/ATVBAHA.120.314048.

3. Ye F, Wang YA, Wu C, Howatt DA, Wu CH, Balakrishnan A, Mullick AE, Graham MJ, Danser AH, Wang J, et al. Angiotensinogen and megalin interactions contribute to atherosclerosis-brief report. Arterioscler Thromb Vasc Biol. 2019;39:150-155. DOI: 10.1161/ATVBAHA.118.311817.

4. Yang JM, Dong M, Meng X, Zhao YX, Yang XY, Liu XL, Hao PP, Li JJ, Wang XP, Zhang K, et al. Angiotensin-(1-7) dose-dependently inhibits atherosclerotic lesion formation and enhances plaque stability by targeting vascular cells. Arterioscler Thromb Vasc Biol. 2013;33:1978-1985. DOI: 10.1161/ATVBAHA.113.301320.

5. Lu H, Rateri DL, Feldman DL, Charnigo RJ Jr, Fukamizu A, Ishida J, Oesterling EG, Cassis LA, Daugherty A. Renin inhibition reduces hypercholesterolemia-induced atherosclerosis in mice. J Clin Invest. 2008;118:984-993. DOI: 10.1172/JCl32970. 